\title{
One Of The Prime Beneficiaries Of The Sarbanes - Oxley Act Of 2002: The London Stock Exchange!
}

RamMohan R. Yallapragada, Fayetteville State University, USA Alfred Toma, University of Louisiana, Lafayette, USA C. William Roe, Arkansas State University, USA

\begin{abstract}
In the late 1990's, financial markets in the United States (US) were rocked by accounting scandals in companies such as Enron and WorldCom. Public confidence in American business was at a low ebb. As a knee-jerk reaction to the scandals, the US Congress hastily passed the Sarbanes-Oxley Act of 2002 (SOX) hoping to restore the lost image of the U S business firms. SOX rendered corporate governance and protecting corporate assets a matter of Federal mandates. Penalties for violation of the provisions of SOX include a maximum of 25 years of prison and/or a fine of twenty five million dollars. For small and mid-size firms, the implementation costs became prohibitive. The exorbitant implementation costs of Section 404 of SOX and the draconian criminal sanctions for senior management are driving companies to flee from The New York Stock Exchange to more favorable exchanges overseas. The London Stock Exchange appears to be the most benefited one from the passage of SOX. This paper presents the salient provisions of SOX, the havoc caused to the business firms by its implementation costs, and the present trend of flight of capital from American stock exchanges to overseas stock exchanges such as the London Stock Exchange.
\end{abstract}

Keywords: Sarbanes-Oxley Act, Corporate Governance, Federal Government, Mandates, Section \#404, Internal Control, Implementation Costs, New York Stock Exchange, London Stock Exchange, Initial Public Offerings

\section{INTRODUCTION}

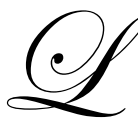
arge scale accounting scandals involving Enron, Global Crossing, Arthur Anderson etc., hit the United States (US) in late 2001 and early 2002, causing lot of confusion and distrust in the US financial markets. Members of both parties, facing the mid-term elections and a very angry electorate, called for stringent legislation. The U S Congress hastily put together a Draconian law sponsored by Senator Sarbanes (DMD) and House Representative Oxley (R-OH) and passed the bill on short order. On July 30, 2002, President Bush as hastily signed the Sarbanes - Oxley Act of 2002 into law, describing it as, "the most far-reaching reforms of American business since the time of Franklin Delano Roosevelt," (Whalen, 2003).

\section{PROVISIONS OF SARBANES - OXLEY ACT}

Sarbanes - Oxley Act of 2002 (Sarbox or SOX), also known as Public Company Accounting Reform and Investor Protection Act Of 2002, was intended to provide a proper accounting framework and rules for public companies. The Act's stated objective is, "to protect investors by improving the accuracy and reliability of corporate financial statements and disclosures made pursuant to the securities laws," (Berger, 2005). SOX seeks to prevent and punish corporate corruption.

Some of the provisions of the law are: 


\section{Title I: Public Company Accounting Oversight Board (PCAOB)}

SOX created a Public Company Accounting Oversight Board (known as the board). The board's functions are to register, oversee, investigate and discipline all Public Accounting Firms (PAF) that audit public companies.

\section{Title III: Corporate Responsibility - Public Company Audit Committees}

- Sarbox requires creation of an audit committee comprising of independent directors of the issuer company.

- $\quad$ The issuer's audit PAF is put under the control of the audit committee.

- $\quad$ The CEO and the CFO of the issuer company shall sign a statement to accompany the audit report certifying that:

$\circ$ The report does not contain untrue statements or material omissions

- The financial statements fairly present the financial condition and the results of operations.

- Such officers are responsible for internal controls of the issuer and its subsidiaries.

- The internal controls are reviewed for their effectiveness within 90 days prior to the report

$\circ$ Any significant changes to the internal control are reported.

- Violators of SEC rules will be barred from serving as directors of any issuer.

- Attorneys appearing before the SEC are to report any violations of securities laws by a public company to the chief legal counsel or the CEO of the company, or directly to the SEC.

\section{Title IV: Enhanced Financial Disclosures}

- $\quad$ Reports filed with the SEC must include all material off-balance sheet transactions and relationships that may have material effect on the financial status of an issuer.

- $\quad$ Prohibits loans to be extended to senior executives.

- $\quad$ Title IV also includes the Notorious Section 404 which requires annual statement of issuer to contain an INTERNAL CONTROL REPORT which shall

○ state that the management is responsible for establishing and maintaining an adequate internal control structure and procedures for financial reporting.

- contain an assessment of the effectiveness of the internal controls.

- $\quad$ Each issuer's auditor shall attest to and report on the assessment made by the management.

\section{Title VIII: Corporate Criminal Fraud and Accountability}

- Increases imprisonment to $\mathbf{2 5}$ years for defrauding shareholders.

- $\quad$ Provides protection to whistleblowers from retaliation by management.

\section{Title IX: White-Collar Crime and Penalty Enhancements}

- $\quad$ Increases penalties for mail and wire fraud from five to TWENTY years in prison.

- Increases penalty for violations of ERISA Act of 1974 to a maximum of $\$ 500,000$ fine and ten years in prison.

- $\quad$ Establishes criminal liability for failure of corporate officers to certify financial reports (10 years) and for willfully certifying a statement knowing it to be false (20 years).

\section{Title X: Corporate Tax Returns}

- $\quad$ Corporate tax returns are to be signed by the CEO. 


\section{Title XI: Corporate Fraud Accountability}

- Amends Federal criminal law to establish a maximum of 20 year prison term for tampering with a record or otherwise impeding an official proceeding.

- Increases penalties for violations of Securities Exchange Act of 1934 up to \$25 million fine and 20 years of prison time.

- Violators are barred from serving as officers or directors of a publicly traded corporation.

\section{THE HIGH COST OF SOX-SECTION 404: COMPLAINTS AGAINST SOX}

The act contains many corporate governance reforms. The vast majority of the Act's provisions are positive, but the many benefits are being eclipsed by section 404. A survey by NASDAQ (2005) indicated that:

1. Sarbox is not the issue, Section 404, implementation costs are the issue.

2. Audit fees have increased permanently. Average cost of Sarbox implementation of a mid size company is over $\$ 1$ million. The cost definitely does not justify the benefit.

3. Even small cap companies are forced to pay up to $\$ 200,000$ for section 404 implementation. A $\$ 200$ million company cannot have the same standards as a $\$ 20$ billion company. One size does not fit all.

4. Audit firms are compelled to be over-conservative and generate higher fees as a result.

5. Auditors keep charging more fees. Audit committee cannot say no. Management cannot say no. Whoever says no will risk being sued if anything goes wrong.

6. Many executives consider SOX as onerous and only fattening the bottom lines of accounting firms while costing business firms billions of dollars.

Steve Forbes (2005) recently delivered a scathing criticism of Sox as follows:

1. Sarbox is a destructive piece of legislation, rushed through congress in the aftermath of the World Com debacle. This ill-thought, hastily written law has cost shareholders and the US economy infinitely more money than Bernie Ebbers and his ilk ever did.

2. SOX imposes hefty costs on publicly held companies. It has become a boon to the accounting industry since in many cases fees have doubled or even tripled.

3. It is not only the billions of dollars of mostly wasted money but the long periods of time top management is spending in trying to comply with Section 404 instead of focusing on running their businesses.

4. The law has inhibited risk taking. Directors and executives must now ask themselves how a particular corporate decision looks in a court of law. The onerous requirements of SOX fall disproportionately on small and mid-cap companies which are the most innovative and entrepreneurial drivers of change in our economy. According to Wallison (2006), "the most far-reaching effect of Sarbox may be indirect and intangible. By placing a congressional Imprimatur on the notion that managements have to be supervised and controlled by independent boards, the act may have set up an adversarial relationship between managements and boards that will, over time, impair corporate risk-taking and thus economic growth."

5. Sarbox removed a salient pillar of corporate form of business, limited liability. It has brought back the equivalent of the centuries old debtor's prison. Unlimited liability means less risk taking and less economic growth.

6. Finally, Sox miserably flunks the cost-benefit analysis too.

\section{GOOD BYE NEW YORK! HELLO, LONDON!}

Schuman (2006) observes that since the time the law was enacted, a growing chorus of critics claimed that Sarbanes-Oxley Act went too far, saddling companies with costly and unnecessary auditing requirements that put $\mathrm{U}$. S. registered companies and the U. S. markets at a global disadvantage. Sox has reduced the competitive power of $\mathrm{U} \mathrm{S}$ business firms in the global markets by subjecting them to enormous Sox compliance costs. Furthermore, because of the onerous requirements of Sox, foreign companies are foregoing the U S stock exchanges for friendlier environments abroad. For instance, the state-owned Russian giant, OAO Rosneft Oil Company plans to go public 
by listing in the London Stock Exchange to raise an estimated $\$ 10$ billion capital, one of the biggest takes ever. A decade ago, the Russian Company would have jumped thru' the loops to have its shares on a U S stock exchange. Rosneft is not alone. Companies are increasingly forsaking the U S for friendlier overseas environs. The New York Stock Exchange and NASDAQ pin much of the blame on the Sarbanes-Oxley Act (Sasseen, et. al., 2006).

Wallison (2006) points out that between 1996 and 2001, the New York Stock Exchange (NYSE) averaged 50 new non-US listings per year. In 2005, it came down to 19. In the same year, the London Stock Exchange and its small affiliate company gained 139 new listings. Since the end of 2004, 30 foreign companies have left the NYSE and NASDAQ. Financial capital involving mergers and acquisitions is also finding more comfortable home abroad. Large new offerings this year involving billions of dollars of Russian aluminum and Kazakhstan oil and copper companies are planning to list in London.

In fact, a recent study by Foley and Lardner found that $20 \%$ of public companies are considering going private just to avoid Sarbox compliance. As Factor (2006) states, "it is no wonder, then, that the London Stock Exchange (LSE) - eager to exploit a competitive advantage - now promotes itself by reminding companies that by listing on the LSE they are not subject to Sarbox." Murray (2006) notes that nine out of ten largest Initial Public Offerings (IPOs) in 2006, and 24 out of 25 largest in 2005 were done in overseas markets. That is a remarkable change from the 1990s, when the vast majority of IPOs were made in the U. S. financial markets (Murray, 2006). Perrin (2006) reports that in a survey of 80 international companies that conducted an IPO on its markets in 2005, the companies first considered listing on U S exchanges but 90 per cent of those companies felt that demands of SOX made listing in London more attractive. Hamlin (2006) recently stated that a senior Hong Kong-based investment banker observed that if his company listed its shares on a U S exchange, then under U S law, he would be personally responsible for what goes on in his company.. He added, "Would you sign off on that? You would be a lunatic to do it!" (Hamlin, 2006).

Brown (2006) found that when Peach Holdings, a Florida based lending outfit wanted to mount an IPO, it shunned U S stock markets and raised \$231 million on the London Stock Exchange's Alternative Investment Market (AIM). Here is the peachy math. It would have had to pay a $\$ 100,000$ fee to list on NASDAQ in addition to over $\$ 2$ million to comply with the onerous burden of the requirements of SOX. To list on AIM, the company spent only $\$ 500,000$ including a fee of $\$ 7,600$ to the London Stock Exchange. According to Byrne (2007), the figures say it all. In the past four years, the total IPOs raised on the NYSE has increased by 167 per cent. During the same period, there was a staggering 998 per cent increase in funds raised on the main listings of LSE. Zhu and Small (2007) observed that the passage of SOX had a "detrimental impact and a chilling effect" on international companies' decisions whether to cross-list in the U S. Perrin (2006) also reports that a University of Rochester study concluded that the overall effect of SOX has reduced the stock value of American companies by a staggering $\$ 1.4$ trillion, so far.

\section{CONCLUSION AND SUGGESTED REMEDIES}

Obviously something is wrong. As Wallison (2006) observes, Sox and its ancillary SEC regulations contributed to a recent Security Industry Estimate that the industry spends $\$ 25$ billion annually on SEC compliance. These costs are naturally passed on to persons and companies that use the U. S. securities markets. A recent study by the London Stock Exchange showed that underwriting costs in London were roughly half of those in the U. S.! DeMint and Feeny (2006) recently introduced legislation that would require the SEC to create alternative provisions for companies that wish to opt out of Section 404 of SOX. The new U. S. Treasury Secretary, Henry Paulson is supporting a committee that was set up to review the SOX law and other aspects of the regulation of capital markets in the U. S. As Perrin (2006) observes, discontent in the U S regarding the Securities and Exchange Commission (SEC) regulatory procedures in the post-SOX era seem to be growing more and more "punitive and adversarial in nature."

A U. S. Chamber of Commerce study wanted the SEC to appoint a committee to examine its enforcement practices. Two U S Lobby groups, the Free Enterprise Fund and the Competitive Enterprise Institute, recently launched a constitutional legal challenge to the creation of the PCAOB by SOX. Powell (2005) suggests a suitable 
solution to the SOX provisions of Section 404. He says that Congress can correct the overreach of SOX by simply making Section 404 mandates on internal controls voluntary, while keeping the rest of the provisions of SOX intact. He suggests that such a scaled-back SOX would help keep the U. S. businesses competitive in the world markets while reaffirming the primacy of free market initiatives and innovation. Former Senators, Bob Dole and Tom Daschle, (2005) suggest that Congress could consider tailoring the certification process to provide for less costly alternatives for smaller businesses. The recommendations of the SEC Advisory Committee on Smaller Public Companies would, if implemented, bring a much sought after relief to small and mid-cap companies from the vagaries of Sarbox.

Dr. RamMohan R. Yallapragada is an Associate Professor of Accounting at Fayetteville State University. He obtained his PhD degree in Accounting from the University of Houston. He holds a CPA certificate from the State of Louisiana. He taught at University of Texas at San Antonio, Nicholls State University, and University of Louisiana, Lafayette before joining FSU. He has published in several journals including Journal of Business and Economic Research, International Business and Economic Research Journal, Journal of Accounting and Finance Research, and Clarion Business and Economic Review. His research areas include Cost Accounting in Healthcare, Accounting irregularities in Fannie Mae, impact of Sarbanes-Oxley Act of 2002 on American corporations and the effect of unprecedented growth in the economies of India and China on global trade.

Alfred G. Toma holds the degrees of M.B.A. from the American University of Beirut, Lebanon and M.Sc in Marketing from Louisiana State University, Baton Rouge. He has co-authored journal articles and/or conference papers in the areas of International Business and Entrepreneurship. He currently teaches courses in International Business Management, Entrepreneurship, and Human Resources Management at the University of Louisiana at Lafayette. His extensive actual business works and consultancy experiences are focused on the areas of entry and operations in Middle East markets and entrepreneurial ventures start-ups.

C. William Roe received his doctorate from Mississippi State University in Management. He has authored/coauthored numerous journal articles and/or conference papers in management, marketing, healthcare administration and international business. He currently serves as Associate Dean and Director of Graduate Business Programs at Arkansas State University. He has consulted extensively with numerous public, private, for-profit, and not-forprofit organizations in the areas of strategic planning, leadership, organizational change and development and management development.

\section{REFERENCES}

1. Berger, David (2005). "Staying Up To Date With The Sarbanes-Oxley Act," www. plantservices.com/articles/2005/

2. Brown, Erika (2006). "London Calling," Forbes, Vol. 177, Issue 10, May 8, 2006, pp. 51-52..

3. Byrne, Malt (2007). “Apple Crumble,” Lawyer, Vol. 21, Issue 9, March 5, 2007, pp. 20-21.

4. DeMint, Jim and Tom Feeny (2006). "Common-Sense Changes," The Wall Street Journal, New York, NY, May 10, 2006, p. A18.

5. Dole, Bob and Tom Daschle (2005). "Let's Reform The Reforms," The Wall Street Journal, (Eastern Edition). New York, NY October 3, 2005, P. A16.

6. Factor, Mallory (2006). "Two Cheers For Nancy Pelosi," The Wall Street Journal, New York, NY, March 18,2006, p. A9.

7. Forbes, Steve (2005). "Dump This Destructive Deadweight," Forbes, September 5, 2005, 31-32.

8. Hamlin, Kevin (2006). "Battling For China's IPOs," Institutional Investor-International Edition, Vol. 30, Issue 12/1, Dec 2005/Jan 2006, pp. 34-40.

1. 9.. Murray, Alan (2006). "Business: Panel's Mission: Easing Capital-Market Rules," The Wall Street Journal, New York, NY, September 12, 2006, p. A2.

9. NASDAQ (2005). "Issuer Survey: Sarbanes-Oxley Act, March 2, 2005," www.SOX404.biz/webdocs/nasdaq_SOX_March2005.pdf, March 2, 2005.

10. $\quad$ Perrin, Sarah (2006). "Escape From New York," Accountancy, Vol. 137, Issue 1352, April 2006, pp. 5253. 
11. Powell, Scott S. (2005). “Costs Of Sarbanes-Oxley Are Out Of Control,” The Wall Street Journal, March 21, 2005, p. A-17.

12. Sasseen, Jane et al. (2006). "Taking Their Business Elsewhere," Business Week, Issue 3985 May 11, 2006, pp. 33-34.

13. Schuman, Joseph (2006). "A Corporate Oversight Rule Looks Set To Be Eased," The Wall Street Journal, New York, NY, November 10, 2006.

14. Wallison, Peter J. (2006). "Capital Punishment," The Wall Street Journal, New York, NY, November 4, 2006, p. A7.

15. Whalen, Christopher (2003). "Revisiting Sarbanes-Oxley,” The International Economy, Washington: Fall 2003, p. 40.

16. Zhu, Hong and Ken Small (2007). "Has Sarbanes-Oxley Led to a Chilling in the U. S. Cross-Listing Market?” CPA Journal, Vol. 77, Issue 3, March 2007, pp. 32-37.

\section{NOTES}

